\title{
Evaluation of an Anti-Monopoly Programme in Hungarian Public Utilities
}

\author{
Tamás M. Horváth
}

\section{INTRODUCTION}

Hungary used to be an example of strong decentralised local government, but that has now changed. The transition system that was introduced in 1990 delegated quite a lot of functions to municipalities. Every settlement was granted local government of its own, but without enough incentives to cooperate in order to be more effective in service provision. The local level was strengthened by the privatisation process in the 1990s, because municipalities received income and shares in this process. Nevertheless, private monopolies then became stronger, sometimes against the interests of local governments and regulatory bodies. The originally introduced wide range of responsibilities and at the same time independence that remained fragmented was not sufficient to

The empirical research was also sponsored by the project OTKA [National Scientific Research Fund, Hungary] K 101147, City Governance in Middle Sized Towns and Urban Areas, led by the author.

T.M. Horváth $(\square)$

MTA-DE Public Service Research Group, Debrecen, Hungary

e-mail: tamas.m.horvath@law.unideb.hu

(C) The Author(s) 2018

I. Koprić et al. (eds.), Evaluating Reforms of Local Public and

Social Services in Europe, Governance and Public Management, https://doi.org/10.1007/978-3-319-61091-7_17 
maintain municipal financial positions strongly enough. So, the level of local democracy was relatively high at the beginning of the system transition, but weaknesses emerged in its effectiveness.

This longstanding tradition of transformation of the system at local and regional levels became the basis of the dramatic turn in the policy of the nation state from 2010. Concerning the municipal system, the government strategy became one of extreme centralisation. Local authorities lost most of their service providing functions; institutions formerly maintained by them were centralised. In addition, regional development became a function of the nation state.

From 2010, several measures were undertaken to centralise profits from the energy, water, waste and other (funeral, park maintenance, chimney sweeping services) public utility sectors. Providers are now burdened with a central tax levied on public utility networks. A general cut in prices of user charges is required and a new supervisory fee has been introduced for an administrative regulatory authority. Additionally, municipal utilities were exempted from some of the taxes, but this is no longer the case and the financial burden for municipal utilities is now heavier, especially for the central government.

All in all the structure of the system formally remained the same at two levels (municipal and county), however, the functional, financial and ownership position of local government has already changed dramatically. In this circumstances local distribution from GDP decreased by onethird, from $11.4 \%$ (2008) to $7.76 \%$ (2014) (OECD).

\section{Theoretical Frameworks and Methods of the Study}

The direct theoretical background of the paper is threefold. First, country-specific but contextual crises studies are based on explanatory research (Hajnal 2014; Hajnal and Rosta 2016) of the present turn in the development of Hungary. Second, different concepts of "re-public" solutions have recently been used as explanatory variables like the concept of remunicipalisation (Hall 2012; Pigeon et al. 2012; Water Remunicipalisation Tracker) and the re-emergence of municipal corporations(Wollmann and Marcou 2010). In addition, the policy of direct centralisation has been scrutinised by Horváth (2016) on this basis. Third, programme evaluation studies of public sector (Wollmann 2003) and institutional reforms (Kuhlmann and Wollmann 2011) at intergovernmental levels are based on the ex-post control of logic in anticipated policy programmes. 
A quantitative, performance, ex-post evaluation is the focus of this study. The relationship to the paradigm of New Public Management (NPM) is at the centre of the evaluation. It has been criticised heavily by the present Hungarian central government, which involves the denial of market-orientation in most of the public services and open competition for foreign investors. National interest is very much emphasised nowadays in public policies, even in sector ones. Official communication is built upon national community-based statements. It seems that voters at least have been convinced notwithstanding the further consequences.

In the meantime, evaluation as a management technique is working in Hungary, linked especially to past and ongoing projects of the European Union. For instance, pre-accession funds (PHARE, ISPA, development funds for small regions) had been evaluated, as well as national development programmes linked to the budget cycles during membership of the EU (since 2004). Recently, in the 2010s, this type of evaluation has been clearly split from the analysis of the national government's programme as a whole, for different reasons. First of all, it is based on different preferences than those focused on by NPM. This paper tries to go back to the NPM view and adopt some components of classical approaches to evaluate, for example, the basis of measurement in effectiveness, rather than ideological attributes.

\section{Policy Programme Design}

After the international credit crisis (2008) and a moderate sovereign debt crisis (in the same decade) the former management structure of public services was questioned in Hungary. Social conflicts led to radicalism in politics. The effect on municipal activities and functions became very restrictive. In response, the regulatory position of the state was enhanced, and central government preferences were greatly widened. In some European countries the crises have led to corrections in the competition policy of public services. In Greece, as a comparable case, municipal overspending had to be abandoned, with a turn to NPM-inspired alternative solutions of service delivery. This policy involves increasing the roles of private actors either as investors or volunteers. In strong contrast, the Hungarian case is one showing a trend towards pure centralism. The Hungarian model has led to an extreme version of central influence leading to extensive state intervention. The aim of the national government seems to be to shift public utilities to non-profit-making services. In this case, the role of municipalities has not yet been specified, nor has the providers' presumed counter interest. 
The corporate government in the infrastructural sector came to the attention of the right wing national government of Viktor Orbán very early after the election win in 2010 and its subsequent re-election in 2014. It obtained a two-thirds majority in both the Parliament and in most of the city assemblies. According to their narrative, the former type of economic power was based on earlier political bargaining called privatisation by liberals, who were leading supporters of the transformation process from the formal system transition (1990) to joining the European Union (2004). The nationalist government coalition, consisting of socalled national conservatives supplemented with Christian Democrats, differentiated from but supported by extremists, wanted to remake originally long-term contracts in order to change the players of the game.

The policy programme on public utilities is involved in the starting manifesto of the government elected in 2010 named as "System of National Cooperation" (SNC). Referring to public utilities there are three main focuses (SNC 2010, 24).

(i) Because of strong market monopolies in service provision the aim of the government is to destroy the power of these companies.

(ii) High energy prices are not justified by the average price levels of the surrounding countries therefore stronger direct regulation and supervision are needed according to the programme.

(iii) Reallocation in ownership structure is the preferred solution of the government against private monopolies.

Changes on the basis of these motives are as follows.

1. The really specific context of the Hungarian case is that the Prime Minister, Viktor Orbán, argued this issue in a political speech in $2014^{1}$ and his general political attitude to the public was that foreign private companies had abused their dominant position by overcharging for their services. That was why the national conservatives wanted to buy back shares of these companies. This was one of the key motivations for changing the political system (Hajnal 2014) and market relations, including public services provision. The national conservative ideology here paradoxically focuses on state-centred solutions for every conflicting social or economic issue. Market orientation shifted to state-centred defence of socalled national interests. 
In the background there is an economic logic linked to user charges. To understand the recent situation let us go back to the transformation process. From that time user charges once again became an important element of public financial transfers. User charges are also forms of systemic financing mainly in public utility services. The long history of transition countries demonstrates that these sources may also be considered transfers depending on the decision regarding which level of government may collect them. In communist countries most urban services, like water and sewerage, central heating and solid waste collection, were free or the price was a symbolic payment. Some services were subsidised centrally, particularly electricity and gas.

In the period of transformation giving these revenues "back" to governments became a decision on financial transfers. This sector transition process was composed of several steps. First, starting from the 1990 s, prices were to be liberalised in the public sector. This was important even if the state enterprises were the only providers at the beginning. Second, conditions for competition had to be established. An emerging market was built up with privatisation for these services parallel with the multiplying number of service providers. This was an opportunity to decide about the application of user charges.

In principle user charges are good for some different purposes of local government. These include covering costs and maximising revenues, and they can act as an incentive for economical use. According to the theory (Bird et al. 1995), the importance of user charges is that municipalities can behave as service providers. It means the correct (roughly marginal cost) price is achieved for public consumers. In the new situation the government politically criticised foreign providers for monopolist user charges. Additionally, after the elections a number of criminal cases were brought against top managers in public utility companies accusing them of political corruption.

2. However, on the basis of this radical political concept, there are quite a few arguments, based on pure economic interests, which seem to explain their motivation. First of all, an easy explanation is shown by the national government with the support of consumer price indexes. It is illustrated in Fig. 1. The interrupted line below (signified by the arrow also) is the level of total Consumer Price Index in Hungary between years 2003 and 2012. The level of water pipe services, solid waste management and disposal, waste 


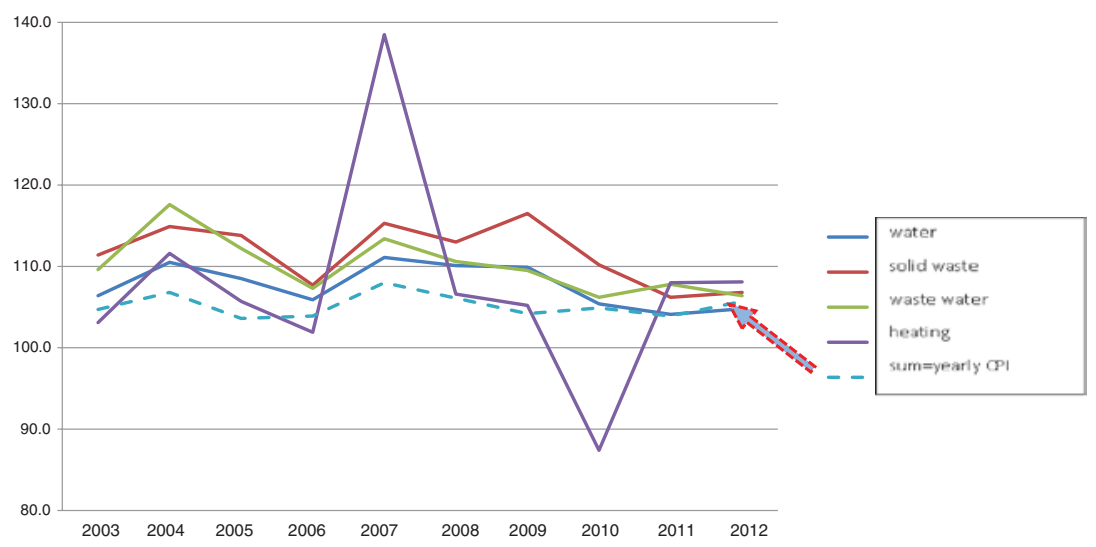

Fig. 1 Trends of consumer price indexes according to consuming in particular public services (2003-2012). Source STADAT COICOP indexes, 2013

water treatment, central heating and warm water services are typically at a higher level continuously. The rise of prices is higher in these sectors than the actual inflation rate. As an exception, an extreme increase in the price of central heating was compensated by the former government. However, others remained on the upper level when the nationalist government started its term from 2010. According to the official argument, utility companies, especially their foreign private owners, pulled out profits from households, that is to say, from "the nation".

3. Behind this argument there are criticisms of two different inherited basic scenarios in the ownership structure of public utility companies which had arisen by the 2000s. One is the model of formerly privatised companies, which was condemned for uncontrolled monopolisation by the new government powers. The other model, of companies remaining in municipal hands, was also criticised heavily, because it was seen as the background of former government parties either at local or national levels.

As far as the first scenario is concerned, it was true that the solutions of privatisation implemented in the public utility sector were rather different. In order to understand this issue properly, let us turn to Bauby 
and Similie's generalised classification (2014). There are two basic specific contractual models on the extension of the private sector in public services. The traditional French legal practice is based on lease and concession contracts. The German model prefers corporative structures in which the operating assets are corporatised and where in the asset holding company the private providing company (the operator of the concession) is a minority shareholder at the same time. From the second half of 1990s the German model was followed in Hungary, with the difference being that not only operating but also core assets (pipelines, networking works) were corporatised in many situations. The importance of this kind of systemic failure was realised about fifteen years later when it became clear that multinational private companies have a strong position mainly in the situation when municipalities as local clients wanted to shift their contracts.

"Who is responsible for this situation?" The question was raised in the systemic turn from 2010, because the solution was against the basic legal regulation of the local government act of 1990, which was passed at the beginning of system transition. Core assets should have been kept in municipal ownership because marketing was prohibited by the law. There are different answers on the responsibility question from the government side, which are as follows:

(a) Former governments. Privatisation had been preferred by central government for many terms before 2010. However, public utility assets had not yet been registered at all. Content of ownership was not defined earlier, especially during the long period of state socialism, where this kind of specification was not in question at all. So, the registry court registered memorandums of new private sector providing companies, without any questions in many situations.

(b) City leaders and politicians who were in office at that time. The new government accused its predecessors of consciously selling off assets, directly furthering only their own interests.

(c) Foreign investors. According to the political rhetoric, international professional companies wanted to obtain a monopoly in order to gain extra profits and only foreign interests were represented by them. It has been emphasised by the government in power since 2010 that some of the West European governments and Länder (German federal member states) are also shareholders in quite a few utility companies providing services in Hungarian cities and regional areas. 
These above-mentioned motives have been inspired by the policy of restructuring in the public service corporate sector during the era of the nationalist government since 2010 .

\section{Reorganisation in the Corporate Sector (Input Changes)}

There have been three basic fields of corporate reorganisation in the Hungarian public utility sector recently: (i) by exclusive rights and burdens against international monopolies (ii) cutting user charges and (iii) reallocation of ownership in the sector.

Acts $^{2}$ passed by the Parliament supported this policy directly through redefining and narrowing groups of authorised providers service by service. In further steps, consumer fees payable by individuals were restricted by the central government by means of direct influence in the market for delivery of services, neglecting any regular tools of regulatory authorities. Municipalities and the national government directly forced buy-back of shares of providing companies from foreign private investors.

(i) Exclusive rights and special taxes. All of the new integrated providers obtained exclusive rights to provide particular services of general economic interests. This action is allowed by the secondary law of the EU. However, in the second phase of restructuring, from 2012, several measures were undertaken by the national government to centralise profits from the energy, water, waste and other (funeral, park maintenance, chimney sweeping services) public utility sectors. This is done by levying special central taxes. Providers are now burdened with taxes levied on public utility networks on the basis of the length of pipes. There is an exemption if the company is $100 \%$ publically owned. Discrimination may be identified in several of the legal procedures, however so far this has not been an obstacle for the implementation of the obligations. Additionally, even municipality-owned providers are burdened with other taxes, like additional income tax on waste management (this burden is also placed upon energy companies), taxes on vacant sites, fees on waste disposal in landfills and so on. In these cases the aim of the central government must have been to centralise business profits, especially not to leave them to municipal owners. 
(ii) User charges. Another phase of the reorganisation in the service providing environment started from the beginning of 2013. From that time the central government has in four waves decreased the consumer fees of particular utility services payable by individual residential users.

The centrally ordered cut on tariffs of utility services was about a nominal 10-25\%. Direct regulation of user charges for utility services became a major focus of the Orbán government and one of its key policy aims. This popular policy ("decreasing burdens on families") was also placed in the centre of the political agenda in order to win the 2014 elections. It was a very successful strategy from the nationalist right wing point of view in the general, EU and subsequent local elections. The political (and not policy) motivation is emphasised by the government in the way that the calculations for the savings of households are prescribed to be put on the official receipt sent out on a monthly basis. The law even requires a coloured (!) background for this notice in order to make sure customers pay enough attention to the effect of the government intervention.

Now let us see the effect of the cut. Table 2 shows the change of customer price indexes in recent years.

The reduction is lower in each item than is prescribed by the law. This must be explained by reference to the discount for individual consumers only. Legal persons and other undertakings have to pay the full price. Nevertheless, their rate is higher now than the original user charge before the direct regulation. In contrast, energy prices have in fact decreased on the world market. In addition, different supplementary services (change of water metre, controls etc.) are more expensive, especially for non-residents. Consequently, the level of service provision is not rising or is effectively worse than it was before. Providers try to escape from the barriers of regulation. For instance, waste collection companies went back to the phase of a fixed frequency-based monthly charge from the existing quantity-based regime.

A clear evaluation of these input changes is shown by the fact that a third of existing solid waste management companies (171 in 2016) are working at a loss as a result of the described management policy.

(iii) Redistribution of influence on ownership in the public utility sector. At the very beginning of the era in new government, policies on 
Table 1 Timetable of the decrease of user charges to individual consumers (according to particular laws)

\begin{tabular}{lll}
\hline Provided service & Date of decrease (from) & Change to price Dec. 2012 \\
\hline Electricity & 01.01 .2013 & $90 \%$ \\
& 01.11 .2013 & $80 \%$ \\
Gas (pipeline) & 01.09 .2014 & $75.44 \%$ \\
& 01.01 .2013 & $90 \%$ \\
District heating & 01.11 .2013 & $80 \%$ \\
& 01.04 .2014 & $74.80 \%$ \\
& 01.01 .2013 & Change to price Nov. 2012 \\
Drinking water & 01.11 .2013 & $90 \%$ \\
Solid waste & 01.10 .2014 & $80 \%$ \\
& & $77.37 \%$ \\
Liquid waste & 01.07 .2013 & Change to price Jan. 2013 \\
Chimney sweeping & 01.07 .2013 & $90 \%$ \\
& 01.07 .2013 & Change to price Apr. 2012 \\
& & $93.78 \%$ \\
\end{tabular}

Source Based on Szemesi (2016), 285-286, prepared in the author's MTA-DE PSRG

municipalities, mainly on cities, were shifted. In the overwhelming majority of cases, party affiliation was the same as that at the central government level. The performance of utility companies was criticised heavily here. The main argument arose as follows:

- high level of consumer fees in comparison,

- little contribution to local municipal revenues,

- dirty businesses,

- liability problems in public contracts.

The answers on these conflicts are different depending on the original ownership position of the state sector. If municipalities sold at least part of their shares earlier, then they wanted to buy back providing companies and the exclusive rights on the delivery of particular services from private owners and managing companies. In cases of companies remaining in the hands of local governments, changes of corporate management were imposed, leading to the establishment of general asset holding companies.

In the countryside, amalgamation of service providers occurred under the umbrella of municipally or centrally owned companies. Private 


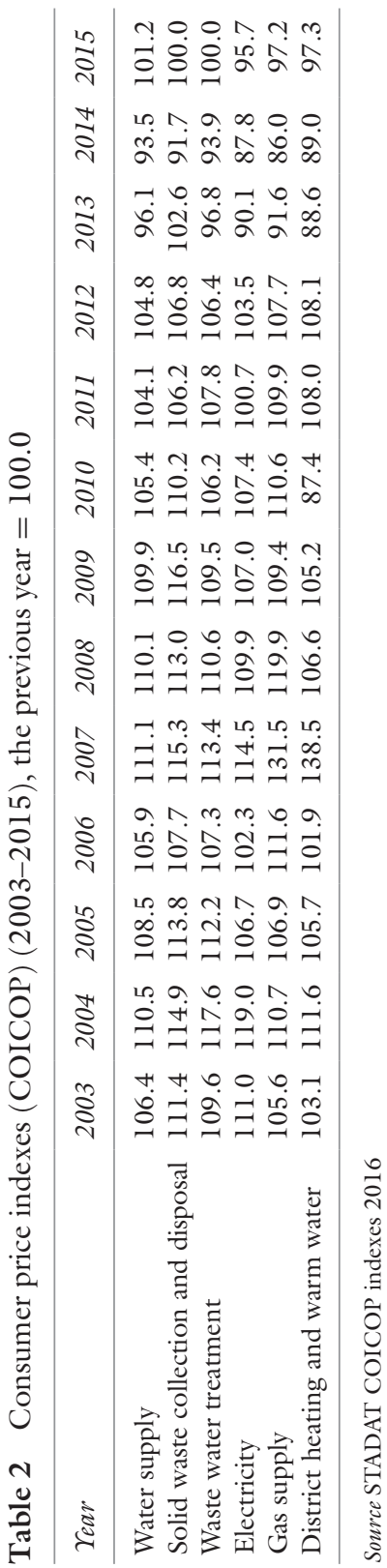


investors were forced by the government with sector laws on different public services to sell their majority shares. For instance, as a result the number of providers in solid waste management decreased by $80 \%$ from 2007 to 2014 . This has meant the integration of delivery service, in addition to change in the identity of the owners.

\section{Direct (Output) Changes}

The whole process of (re)transformation in the public utility sector can be summarised as follows. The central government is extremely active in making rules for the economic environment of public utility service provision in this country. Since 2010 , several measures have been undertaken to centralise profits from the energy, water, waste and other (funeral, park maintenance, chimney sweeping services) public utility sectors.

Providers are now burdened with a central tax levied on public utility networks. The general cut in prices of user charges is supplementary and a new supervisory fee has been introduced for an administrative regulatory authority. Additionally, municipal utilities were exempted from some of the taxes, but this is no longer the case and the financial burden for municipal utilities is now heavier. Although maintenance costs are covered by user charges, tariffs are however defined by Parliament and the government. As far as working capital investments are concerned, because the company is fully owned by municipalities or the state, paradoxically, national and European Union grants were more easily available because no further guarantee was needed for keeping the new utilities in public hands.

The national government obtained ownership in two ways. First, it was done by buying back shares from foreign investors, pressing them by reallocation in the market environment. It took place mainly in gas, electricity and water services. Second, this policy is also implemented by taking over shares from municipalities, as happened in water, waste, waste water and chimney sweeping services. This latter strategy focused on services for residents.

The further aim of the national government seems to be to shift public utilities to non-profit-making services. In this case, neither the role of municipalities nor the providers' presumed counter interest has been specified. This process must have an effect on the public service level in a medium-term perspective. 
Table 3 Effects of cutting consumer prices according to public opinion

\begin{tabular}{lllll}
\hline $\begin{array}{l}\text { The effect of cutting con- } \\
\text { sumer prices is... }\end{array}$ & \multicolumn{2}{c}{ Mean (scale of 4) } & \multicolumn{2}{c}{$\begin{array}{l}\text { Ratio of fully or almost } \\
\text { agreeing }(4,3)\end{array}$} \\
\cline { 2 - 5 } & 2013 & 2015 & 2013 & 2015 \\
\hline $\begin{array}{l}\text { To prevent owners from } \\
\text { getting too high profit }\end{array}$ & 2.93 & 2.82 & $68.1 \%$ & $62.0 \%$ \\
$\begin{array}{l}\text { To make incentives for } \\
\text { public utility companies to } \\
\text { work more effectively }\end{array}$ & 2.65 & 2.76 & $56.1 \%$ & $60.3 \%$ \\
$\begin{array}{l}\text { That less resources remain } \\
\text { for renewal and develop- } \\
\text { ment of networks }\end{array}$ & 2.71 & 2.75 & & \\
$\begin{array}{l}\text { That service level is going } \\
\text { to be lower and less guar- } \\
\text { anteed }\end{array}$ & 2.57 & 2.54 & $55.6 \%$ & $60.1 \%$ \\
\hline
\end{tabular}

How do you agree with that...

fully agree $=4 \ldots$ fully disagree $=1$, mean of valid answers; sample 1200

The logic framework of the whole transfer of the system was tested in detail by our primary analyses. ${ }^{3}$ In a representative sample, residents were questioned about the conditioned content and the expected results of the reduction of consumer fees in public utility services by central government. A sample of 1200 residents were interviewed in 2013 and 2015 by the professional public opinion research institute in the framework of our project.

Questions were asked as to the effects of the cutting of consumer prices. The residents agreed that owners should not get too high a level of profit. They also expressed hope at making incentives for providers more effective. However, opinion on restriction in renewal and development is more and more realised. There is a significant rise from the first to the second survey in the ratio of those who anticipated declining levels of service provision. Data are shown in Table 3.

Finally (by 2015) opinion about cutting consumer prices had become a little worse (Table 4). This means fewer people thought that it was a very good decision, and a higher ratio now thought it a bad or very bad decision.

Although decisions of government may be very favourable to them, consumers' significant ratio faces future negative effects. 
Table 4 Evaluation

of the decision to cut consumer prices according to the public $N=1200$

\begin{tabular}{lcc}
\hline Cutting of consumer prices & 2013 & 2015 \\
\hline it is not known & $5.5 \%$ & $5.5 \%$ \\
it was a very bad decision & $2.6 \%$ & $4.6 \%$ \\
it was a bad decision & $10.1 \%$ & $15.9 \%$ \\
it was a good decision & $50.3 \%$ & $50.4 \%$ \\
it was a very good decision & $31.5 \%$ & $23.6 \%$ \\
total & $100.0 \%$ & $100.0 \%$ \\
mean & 3.17 & 2.98 \\
\hline
\end{tabular}

Source data survey 2013 and 2015 (the authors' data)

\section{IndiRECT (FAR-REACHING) CHANGES}

There are also indirect effects of the official public utility policy. First, infringement procedures by the European Commission are taking place ${ }^{4}$ because prices are defined by the ministry instead of the regulatory authority. In addition, specific taxes, like a tax on the length of pipe networks and energy transaction fees, must not be calculated as an accepted cost.

Second, the competition aspect is challenged. There are different prices for individuals and for undertakings, which appears to be discrimination. Newly established huge state-owned enterprises are in a better position in tenders, avoiding formal public procurement processes. Several antitrust procedures have been initiated for this reason. Although keeping state aid rules is also questioned, there are fewer of these kinds of disputes in European institutions.

Third, international investment disputes are taking place, because semi-nationalisation procedures under the new state-owned property act and the actions of municipalities and the national state are questioned by private, especially foreign, investors.

Fourth, an indirect effect has been highlighted. Charges in the global market of the energy sector have decreased, while the Hungarian government froze prices at a static level.

Fifth, the government's own public relations and propaganda focuses on the cutting of charges in the utility sector. It is one of the key issues of the campaign called "The Hungarian reforms are working!". The most important figures that show the savings are required to be printed on receipts sent to householders monthly. This policy has been an important strategy of the national government since the beginning of 2013 .

Sixth, some sector providers have become bankrupt, in such areas as chimney sweeping, as well as many waste companies. In these cases the 
national authority of civil defence becomes responsible for fulfilling public tasks, neglecting market actors all together.

All in all, according to experts and scholars (Pappas 2014; Szelényi and Csillag 2015; Hajnal and Rosta 2016), the legality deficit is quite serious in general in this situation whether in the economic or political field. The tactics of the government have been realised mostly with "success", because legal procedures are long term for example, four-six years are needed, while advantages are realised in financial and interest-based power games. The price of it is to be paid by the public as a whole.

\section{LESSONS LEARNT}

Table 5 summarises the mentioned phenomena, grouping and adding non-anticipated (non-intended) effects. As has already been shown, it is difficult in this case to term the actions of the government "reforms", because the focus of the measures is more the reassessment of former preferences rather than improvement as such. As Prime Minister Viktor Orbán said in his speech at the national celebration on 15 March 2016, "our results cannot be measured only with utilisation, but the totality

Table 5 Evaluation of reform/reassessment on the basis of the scrutinised case

\begin{tabular}{|c|c|c|c|}
\hline $\begin{array}{l}\text { [Reform]/ } \\
\text { Reassessment }\end{array}$ & Input changes & Output changes & Far-reaching changes \\
\hline $\begin{array}{l}\text { [Intended]/ } \\
\text { Anticipated by gov- } \\
\text { ernment efforts }\end{array}$ & $\begin{array}{l}\text { - Enhancing public } \\
\text { ownership } \\
\text { - Exclusive rights } \\
\text { - Special taxes } \\
\text { - PR against private } \\
\text { monopolies }\end{array}$ & $\begin{array}{l}\text { - Amalgamation of } \\
\text { providers } \\
\text { - Change elites in } \\
\text { corporate manage- } \\
\text { ment } \\
\text { - Cut of user } \\
\text { charges }\end{array}$ & $\begin{array}{l}\text { - Neglecting com- } \\
\text { petition } \\
\text { - Nationalisation } \\
\text { - Restriction in the } \\
\text { EU integration }\end{array}$ \\
\hline $\begin{array}{l}\text { [Unintended]/ } \\
\text { Non-anticipated } \\
\text { (but expected?) by } \\
\text { government efforts }\end{array}$ & $\begin{array}{l}\text { - Increasing transac- } \\
\text { tion costs }\end{array}$ & $\begin{array}{l}\text { - Constraints on } \\
\text { increasing the } \\
\text { service level } \\
\text { - Decrease of mort- } \\
\text { gage rates } \\
\text { - Bankrupting } \\
\text { providers }\end{array}$ & $\begin{array}{l}\text { - Infringement } \\
\text { procedures } \\
\text { - International } \\
\text { investment disputes } \\
\text { - Drop of consumer } \\
\text { orientation }\end{array}$ \\
\hline
\end{tabular}

Source Edited by the author 
should be our preference". That is why reassessment is a better term, supplemented with reforms, to characterise the process in policymaking, instead of highlighting real sector policies.

It must be clear from Table 5 that anticipated far-reaching objectives are very much interest-based. Comparing anticipated and non-anticipated aims we can conclude that the advantages of the intended effects are distributed to particular social and economic groups, while disadvantages are placed upon others.

Are these investigated actions really reforms or simply a package of intervention in order to achieve political aims? First, according to our research, at least we are sure to state that as a result of the implementation of utility policies recently in Hungary, service levels did not improve. Our starting hypothesis that the reform rhetoric of NPM is not working in these circumstances, because the orientation of changes is clearly out of the question of public service performance, seems to have been proved.

Second, this failure is not based on lack of clarification. Goals of the government were clear enough and these were realised in a quite systemic way. Nevertheless, either competition in liberalised markets or consumer orientation are simply neglected by these aims; instead, clear values of economic and political power are preferred on public utility service provision.

\section{Notes}

1. Orbán's speech in Tusnádfürdő (Baile Tusnad, Romania, 26.07.2014) about his political programme to an exclusive audience in Transylvania. https://www.youtube.com/watch?v=PXP-6nlG8ls.

2. See the list of the acts in the Annex.

3. The whole following empirical analysis is based on the author's primary research, funded by OTKA (cited in the footnote 1 ).

4. http://hungarianspectrum.org/tag/third-energy-package/.

\section{REFERENCES}

Bauby, P., \& Similie, M. (2014). Europe United cities and local governments. Basic services for all in an urbanizing world (pp. 94-131). Abingdon: Routledge.

Bird, R. M., Ebel, R. D., \& Wallich, C. E. (1995). Decentralization of the socialist state: Intergovernmental finance in transition economies. Washington: The World Bank. 
Hajnal, G. (2014). Unorthodoxy at work: An assessment of Hungary's post-2010 governance reforms. Available at: https://www.researchgate.net/publication/273447223_UNORTHODOXY_AT_WORK_AN_ASSESSMENT_ OF_HUNGARY'S_POST-2010_GOVERNANCE_REFORMS. Accessed 15 Oct 2016.

Hajnal, G., \& Rosta, M. (2016). A new doctrine in the making? Doctrinal foundations of sub-national governance reforms in Hungary (2010-2014). Available at: https://www.researchgate.net/publication/292346727_A_ New_Doctrine_in_the_Making_Doctrinal_Foundations_of_Sub-National_ Governance_Reforms_in_Hungary_2010-2014. Accessed 15 Oct 2016.

Hall, D. (2012). Re-Municipalising municipal services in Europe. Available at: http://www.epsu.org/article/re-municipalising-municipal-services-europe. Accessed 15 Oct 2016.

Horváth, T. M. (2016). From municipalisation to centralism: Changes in the Hungarian local public service delivery. In I. Kopric, G. Marcou \& H. Wollmann (Eds.), Public and social services in Europe. From public and municipal to private sector provision (pp. 135-149). Basingstoke: Palgrave Macmillan.

Kuhlmann, S., \& Wollmann, H. (2011). The evaluation of institutional reforms at sub-national government levels: A still neglected research agenda. Local Government Studies, 37(5), 479-494.

Pappas, T. S. (2014). Populist democracies: Post-authoritarian Greece and postcommunist Hungary. Government and Opposition, 49(1), 1-23.

Pigeon, M., McDonald, D. A., Hoedeman, O., \& Kishimoto, S. (2012). Re-municipalisation: Putting water back into public hands. Amsterdam: Transnational Institute.

SNSC. (2010). System of National Social Cooperation. Available at: www.miniszterelnok.hu/attachment/0009/8616_00047.pdf. Accessed on 25 Oct 2016.

Szelényi, I., \& Csillag, T. (2015). Drifting from liberal democracy: Neo-conservative ideology of managed illiberal democratic capitalism in post-communist Europe. Intersections. East European Journal of Society and Politics, 1(1), 18-48.

Szemesi, S. (2016). A közszolgáltatások kormányzati díjcsökkentési kérdései nemzetközi jogi összefüggésben. In T. M. Horváth and \& I. Bartha (Eds.), Közszolgáltatások megszervezése és politikái Merre tartanak? (pp. 278-287). Budapest: Dialóg Campus.

Wollmann, H. (2003). Evaluation in public sector reform: Concepts and practice in international perspective. Cheltenham: Edward Elgar.

Wollmann, H., \& Marcou, G. (2010). The provision of public services in Europe: Between state, local government and market. Cheltenham: Edward Elgar.

Web sources.

http://www.remunicipalisation.org. Accessed on 25 Oct 2016. 


\section{Author Biography}

Tamás M. Horváth is Leader of MTA-DE Public Service Research Group and Professor at the University of Debrecen. He is Head of Department of Financial Law and Public Management, Faculty of Political and Legal Studies. Formerly he was Deputy Director General in the Hungarian Institute of Public Administration. He has got practices in different fields of public and public-private law. His professional interests are judicial case law of subsidies, metropolitan public utility services, regulatory functions in public sector, comparative local government reforms. 
Maria Tullia Galanti Department of Social and Political Sciences, University of Milan, Milan, Italy

Marieke van Genugten Institute for Management Research, Radboud University, Nijmegen, The Netherlands

Marco Di Giulio Department of Management, Economics and Industrial Engineering, Politecnico di Milano, Milan, Italy

Tamás M. Horváth MTA-DE Public Service Research Group, Debrecen, Hungary

Kurt Houlberg KORA, The Danish Institute for Local and Regional Government Research, Copenhagen, Denmark

Vicki Johansson School of Public Administration, University of Gothenburg, Gothenburg, Sweden

Martin Laffin School of Business and Management, University of London, London, UK

Lena Lindgren School of Public Administration, University of Gothenburg, Gothenburg, Sweden

Andrea Lippi Department of Political and Social Sciences, University of Florence, Florence, Italy

Romea Manojlović University of Zagreb, Zagreb, Croatia

Beata Mikušová Meričková Matej Bel University, Banská Bystrica, Slovakia

Łukasz Mikuła Institute of Socio-Economic Geography and Spatial Management, Adam Mickiewicz University, Poznań, Poland

Łukasz Mikuła Adam Mickiewicz University, Poznań, Poland

Stig Montin School of Public Administration, University of Gothenburg, Gothenburg, Sweden

Anamarija Musa Faculty of Law, University of Zagreb, Zagreb, Croatia Carla Puiggrós Mussons Fundació Carles Pi I Sunyer, Barcelona, Spain Juraj Nemec Masaryk University, Brno, Czech Republic 


\section{Contents}

Evaluating Reforms of Local Public and Social Services in Europe

Ivan Koprić and Hellmut Wollmann

Regulatory Impact Assessment and Sub-national Governments

Gérard Marcou and Anamarija Musa

Less Plato and More Aristotle: Empirical Evaluation of Public Policies in Local Services

Germà Bel

The Politics of Evaluation in Performance Management Regimes in English Local Government

Martin Laffin

Evaluating Personal Social Services in Germany

Hellmut Wollmann and Frank Bönker

Healthcare Marketisation in Spain: The Case

of Madrid's Hospitals

José M. Alonso, Judith Clifton and Daniel Díaz-Fuentes 
The Institutionalisation of Performance Scrutiny

Regimes and Beyond: The Case of Education

and Elderly Care in Sweden

Stig Montin, Vicki Johansson and Lena Lindgren

The Organisation of Local Education in Poland:

An Evaluative Approach to the Outsourcing Model

Łukasz Mikuła and Marzena Walaszek

Reforming Local Service Delivery by Contracting Out?

Evaluating the Experience of Danish Road

and Park Services

Kurt Houlberg and Ole Helby Petersen

The Efficiency of Local Service Delivery:

The Czech Republic and Slovakia

Jana Soukopová, Beata Mikušová Meričková and Juraj Nemec

Effects of External Agentification in Local Government:

A European Comparison of Municipal Waste Management

Harald Torsteinsen, Marieke van Genugten, Łukasz Mikuła,

Carla Puiggrós Mussons and Esther Pano Puey

The Emergence of Performance Evaluation

of Water Services in France

Pierre Bauby and Mihaela M. Similie

Evaluation of Delivery Mechanisms in the Water

Supply Industry-Evidence from Slovenia

Primož Pevcin and Iztok Rakar

Apprentice Sorcerers. Evaluating the Programme Theory of Regulatory Governance in Italian Public Utilities

Giulio Citroni, Marco Di Giulio, Maria Tullia Galanti, Andrea Lippi and Stefania Profeti

Evaluation of the Decentralisation Programme in Croatia: Expectations, Problems and Results 
Evaluating the Impact of Decentralisation on Local Public Management Modernisation in Croatia

Jasmina Džinić and Romea Manojlović

Evaluation of an Anti-Monopoly Programme in Hungarian Public Utilities

Tamás M. Horváth

Metropolitan Municipality Reform: Rescaling of Municipal Service Delivery in Turkey

Yeseren Elicin

Policy Evaluation Capacity in Greek Local Government:

Formal Implementation and Substantial Failures

Theodore N. Tsekos and Athanasia Triantafyllopoulou

Lessons Learned from Successful and Unsuccessful Local Public and Social Service Delivery Reforms

Ivan Koprić

Index 
GOVE ANCE AND PUBL MANAGEMENT SERIES

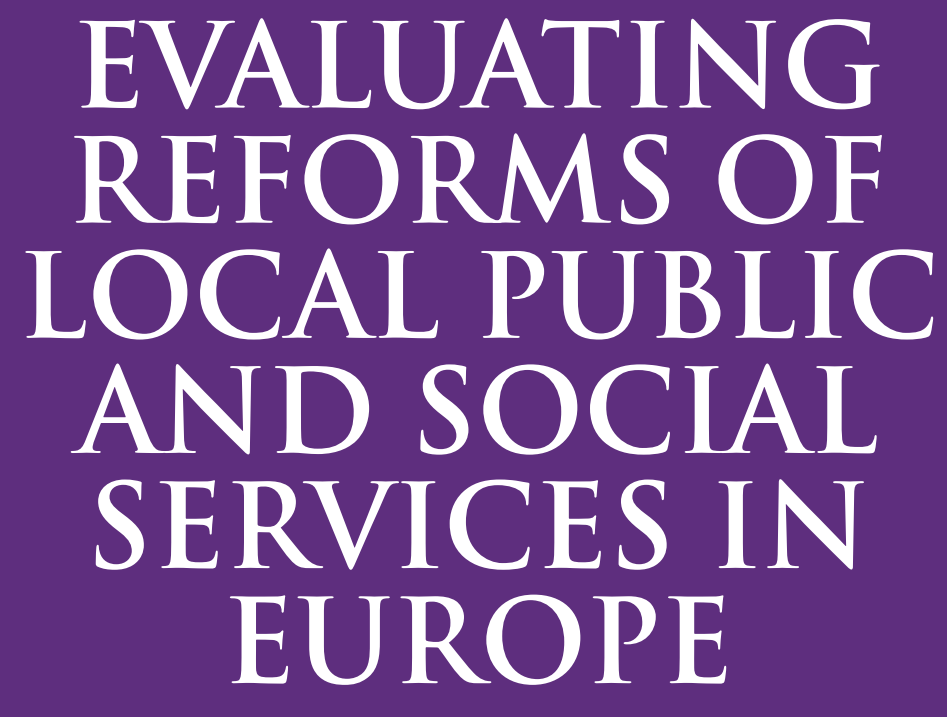

\section{MORE EVIDENCE FOR BETTER RESULTS}

EDITED BY IVAN KOPRIĆ, HELLMUT WOLLMANN, GÉRARD MARCOU 